Lidia Dakowicz, PhD, https://orcid.org/0000-0001-6424-1370

Faculty of Education

University of Bialystok

\title{
Specificity of the affective sphere of spouses with higher and lower levels of transgression
}

\author{
Specyfika sfery afektywnej małżonków \\ o wyższym i niższym poziomie transgresji ${ }^{1}$
}

https://doi.org/10.34766/fetr.v48i4.942

\begin{abstract}
Within the understanding of psychotransgressionism, personality is a network of five equipollent psychons: cognitive, instrumental, motivational, emotional and personal. The strength of the individual psychons lies at the basis of the tendency to undertake transgressive actions of a prodevelopment nature. In the presented research, we focused on the affective sphere of spouses as a manifestation of the functioning of one of the psychons - emotional. The analysis of the results obtained confirmed the assumed hypothesis. Spouses with a higher level of transgression were characterized by a greater positive affective shift than spouses with a lower level of transgression. The emotional climate brought into mutual relations by spouses with a higher level of transgression may foster building satisfying and stable marital relationships.
\end{abstract}

Keywords: psychotransgressionism, network theory of personality, the emotional psychon, positive affective shift

\begin{abstract}
Abstrakt: $\mathrm{W}$ ujęciu psychotransgresyjnym osobowość stanowi sieć pięciu równoważnych psychonów, których zawartość determinuje jej funkcjonowanie. Siła poszczególnych psychonów leży u podłoża skłonności do podejmowania działań transgresyjnych mających charakter prorozwojowy. W prezentowanych badaniach skupiono się na sferze afektywnej małżonków jako przejawie funkcjonowania jednego z psychonów - emocjonalnego. Analiza uzyskanych wyników potwierdziła założoną hipotezę. Małżonkowie o wyższym poziomie transgresji charakteryzują się znacznie większym pozytywnym przesunięciem afektywnym, niż małżonkowie o niższym poziomie transgresji. Klimat emocjonalny wnoszony do wzajemnych relacji przez małżonków o wyższym poziomie transgresji może sprzyjać budowaniu satysfakcjonujących i stabilnych związków małżeńskich.
\end{abstract}

Słowa kluczowe: psychotransgresjonizm, sieciowa teoria osobowości, psychon emocjonalny, pozytywne przesunięcie afektywne

\section{Introduction}

Dynamic cultural changes impact the way of life and choices made by individuals. Widespread promotion of a culture of ensuring one's own pleasure (Hahne, 2004), single living or in open relationships (Walker, 2004) have caused that increasingly frequently the decision to enter into a marriage is delayed, which has resulted in an increase in the average

\footnotetext{
${ }^{1}$ Artykuł w języku polskim dostępny jest na stronie:

https://www.stowarzyszeniefidesetratio.pl/Presentations0/2021-4Dako2.pdf
} 
age men and women get married. However, this increase is not always connected with increased psychological maturity to share one's life with someone (Bennett, 2017). A consequence of this is the quality of the marital relationships formed, which has been the subject of numerous studies (Cherlin, 2004; Carr et al., 2014; Goddard et al., 2016; Slatcher \& Schoebi, 2017) and defined in various ways. The most often used terms include: marital success (Madison \& Madison, 2013), marital happiness (Tsang et al., 2003), marital satisfaction (Bradley \& Hojjat, 2016; Polenick et al., 2017), marital integration (Wojaczek, 2015), well-matched marriage (Gelain et al., 2013), and marriage permanence (Willoughby, 2015). An important element determining the quality of a marital relationship is the emotional sphere, which can be affected by many factors (Frye et al., 2020; Janik McErlean \& $\mathrm{Lim}, 2020)$. One of them, within the understanding of psychotransgressionism, is a greater or lesser tendency of spouses to undertake transgressive actions (Dakowicz, 2014a).

\section{Background}

People undertake two different types of actions: protective and transgressive. The former are of a defensive or palliative nature, which means they protect from physical and psychological pain, and enable maintaining relative stability. In a marital relationship, this is exhibited through undertaking various household duties, and avoiding friction, misunderstandings and conflicts. A transgressive action consists of going beyond everyday reality and doing new things or in a new way (Dakowicz, 2015a). Most often it is related to recognition of emerging difficulties, searching for their causes and undertaking common steps to overcome them (Dakowicz, 2014b). Spouses want to change something in their relationship, expecting an improvement, a deeper relation, but they are also taking a risk that things could get worse. Telling a spouse about one's fears pertaining to the current situation may end in empathetic support and actual help or in an unpleasant experience of the problem being disregarded, misunderstood, or even indifference (Kimmes et al., 2015).

Undertaking any sort of action, specifically transgressive, within the marital reality depends on the spouses' personalities. Kozielecki (2007) suggest a new perception of personality as a network of five relatively permanent and equipollent psychological components, called psychons (cognitive, instrumental, motivational, emotional, and personal), which function as a whole cementing a sense of identity and enabling interaction with the environment. This approach is similar to the five-factor model by Costa and McCrae (1992), who reduced personality to five basic domains: neuroticism, extraversion, openness to experience, agreeableness, and conscientiousness.

In accordance with Kozielecki's network theory of personality, the cognitive psychon includes knowledge about their partner and marital life, among others, expanding the cognitive sphere without which it would be difficult to maintain closeness while facing life's 
ups and downs (Gottman \& Silver, 1999). The next psychon - instrumental - affects how spouses carry out everyday tasks and solve unusual problems. An important element of this psychon is intelligence, which is understood as the ability to handle new situations by referring to previous experiences using one's own cognitive processes (Sternberg, 1997). The motivational psychon is based on needs connected with functioning in the material world, cognitive, social, and internal spheres. These needs start a motivational process, determine the general direction and maintain it, as well as affect finishing undertaken thoughts or actions (Taormina \& Gao, 2013). The emotional psychon consists of lasting neurophysiological and psychological systems generating emotional states, processes, affects and moods, which are accompanied by somatic changes, characteristic facial expressions and behaviors (Ekman, 1992; Parkinson, 2019). Presumably, positive rather than negative emotions play a greater role in transgressive acts, which Kozielecki calls "a positive affective shift" (2007, p. 135). The personal psychon is a deep neurophysiological, psychological, and spiritual structure, containing a person's existential and identity data (Różycka \& Skrzypińska, 2011). These are encoded in conscious beliefs and almost inexpressible conscious states. The most important of these are a belief in (feeling of): one's own existence as a person and causative agent, affirmation of reality, and one's singularity, integrity, continuity, and uniqueness (Kozielecki, 2007).

The aim of the research is an attempt to define the relationship between transgression and the emotional sphere of spouses. Based on the assumptions of psychotransgressionism, it was assumed that the higher level of transgression of spouses would be accompanied by the greater power of the emotional psychon, expressed in the prevalence of positive emotional feelings over negative ones. There were formulated the following hypotheses:

$\mathrm{H} 1$ : Spouses with a higher level of transgression are characterized by a predominance of positive emotional connotations than spouses with a lower level of transgression.

H2: Spouses with a lower level of transgression are characterized by a predominance of negative emotional connotations than spouses with a higher level of transgression.

This study, using the psychotransgressive approach, was of an explorative nature, enabling - due to the obtained results - determining possible further directions of detailed research into factors affecting the quality of a marital relationship.

\section{Method}

Selection of the studied marriages, measurement techniques of transgression level and the affective sphere of spouses were tied to defined operational assumptions taking into account the psychotransgressive approach (Dakowicz, 2015b).

In order to collect a research material from fairly homogeneous group there were taken criteria, which allows spouses to take a part in. The study included 200 couples in their 
first formal marriage, with a minimum of 5 years duration, with secondary education or higher, who were professionally active, and performed parental functions. On the basis of the results obtained using the Transgression Scale (Studenski, 2006), we found 30 wives with a higher level of transgression (WHT - min. result 64, max. 86), 30 husbands with a higher level of transgression (HHT - min. result 66, max. 81), 30 wives with a lower level of transgression (WLT - min. result 27, max. 44), and 30 husbands with a lower level of transgression (HLT - min. result 26, max. 45).

Table 1. Characteristics of the studied spouses

\begin{tabular}{|c|c|c|c|c|c|}
\hline \multicolumn{2}{|c|}{ Selected characteristics } & $\begin{array}{c}\text { Wives } \\
\text { with higher } \\
\text { level of } \\
\text { transgression } \\
(\mathrm{N}=30)\end{array}$ & $\begin{array}{l}\text { Husbands } \\
\text { with higher } \\
\text { level of } \\
\text { transgression } \\
\quad(\mathrm{N}=30)\end{array}$ & $\begin{array}{c}\text { Wives } \\
\text { with lower } \\
\text { level of } \\
\text { transgression } \\
(\mathrm{N}=30)\end{array}$ & $\begin{array}{l}\text { Husbands } \\
\text { with lower } \\
\text { level of } \\
\text { transgression } \\
\quad(\mathrm{N}=30)\end{array}$ \\
\hline \multirow{2}{*}{\multicolumn{2}{|c|}{ Transgression level }} & $\mathrm{M} \quad \mathrm{SD}$ & M $\quad$ SD & $\mathrm{M} \quad \mathrm{SD}$ & M $\quad$ SD \\
\hline & & $70.1 \quad 5.9$ & $71.9 \quad 4.2$ & $39.9 \quad 4.2$ & $39.7 \quad 4.7$ \\
\hline Age & & 35.5 years & 35.9 years & 37.5 years & 38.9 years \\
\hline \multirow{2}{*}{ Education } & higher & $25(83.3 \%)$ & $27(90 \%)$ & $22(73.3 \%)$ & $16(53.4 \%)$ \\
\hline & secondary & $5(16.7 \%)$ & $3(10 \%)$ & $8(26.7 \%)$ & $14(46.6 \%)$ \\
\hline \multicolumn{2}{|c|}{ Marriage duration } & 11.4 years & 10.8 years & 13.5 years & 13.5 years \\
\hline \multirow{5}{*}{$\begin{array}{l}\text { Number of } \\
\text { children }\end{array}$} & one & $15(50 \%)$ & $9(30 \%)$ & $13(43.3 \%)$ & $9(30 \%)$ \\
\hline & two & $11(36.7 \%)$ & $16(53.4 \%)$ & $13(43.3 \%)$ & $9(30 \%)$ \\
\hline & three & $4(13.3 \%)$ & $3(10 \%)$ & $3(10 \%)$ & $11(36.7 \%)$ \\
\hline & four & 0 & $1(3.3 \%)$ & $1(3.3 \%)$ & $1(3.3 \%)$ \\
\hline & five & 0 & $1(3.3 \%)$ & 0 & 0 \\
\hline
\end{tabular}

The Transgression Scale, developed by Studenski (2006) in accordance with Kozielecki's (2007) concept of psychotransgressionism, quantifies the level of transgression through self-described participation of the studied spouses in the realization of transgressive aims. It contains 23 statements that the studied spouses respond to obtaining a specific number of points, which is a sum of choices made for each statement. These choices included one of five variants: definitely yes (4 points), yes ( 3 points), difficult to say ( 2 points), no (1 point) and definitely no ( 0 points). Reversed scoring applies to three statements. The conducted factor analysis of the contents of individual statements found four types of transgressive actions: 1) focus on dominating over others as well as broadening one's own rights and influences; 2) innovation used in designing new solutions as well as determination in realizing own goals; 3) motivation to improve competences, including knowledge, skills and experiences; 4) courage to undertake new tasks that are difficult and 
risky. The high psychometric properties of the scale along with the high convergence of content contained in isolated factors with transgressive actions prove that it is a fitting tool for measuring transgressionism (Studenski, 2006). The specificity of the affective sphere was defined using the semantic differential scale (Rubin \& Babbie, 2008), which enabled spouses to express their personal emotional connotations in reference to twelve concepts connected to four spheres of their lives: general existence (i.e., health), family of origin (i.e., mother), current family (i.e., child), and work (i.e., salary). The studied spouses had the task of marking on a seven-grade scale how they associate statements between extreme positive and negative terms (for example, warm - cold) in their subjective feelings. To avoid automatic responses (all positive or all negative), the individual measures were presented in alternate directions: positive - negative, negative - positive. For the seven-grade scale, we adopted the following interpretation scheme: marking the middle range of the scale expressed neutral emotional connotations; marking one of three sections from the positive side, for example "warm," was an expression of a positive affective shift; and marking one of three sections from the negative side, for example "cold," was an expression of a negative affective shift. The total sum of marked associations by the studied spouses for the individual concepts enabled meaningful assessment if generally a positive affective shift, a negative affective shift, or a neutral state dominated. When developing the obtained results, we used SPSS 23.0 PL software for Windows, which we used to calculate the value of the Mann-Whitney test for the compared groups of spouses with higher and lower levels of transgression (Field, 2013).

\section{Results}

Wives with higher and lower levels of transgression differed significantly in terms of the affective sphere (Table 2). Positive emotional connotations of wives with a higher level of transgression were emphatically greater than wives with a lower level of transgression (Mann-Whitney test $=295.000, p<.005$ ). While negative emotional connotations of wives with a higher level of transgression were emphatically weaker than wives with a lower level of transgression (Mann-Whitney test $=302.000, p<.006$ ). There were no differences in the statistical significance level between the studied groups of wives in the case of neutral emotional connotations.

Table 2. Emotional connotations of wives

\begin{tabular}{lccccc}
\hline \multirow{2}{*}{$\begin{array}{c}\text { Type of } \\
\text { connotation }\end{array}$} & \multicolumn{2}{c}{$\begin{array}{c}\text { Wives with higher level } \\
\text { of transgression }(\mathrm{N}=30)\end{array}$} & \multicolumn{2}{c}{$\begin{array}{l}\text { Wives with lower level } \\
\text { of transgression }(\mathrm{N}=30)\end{array}$} & $\begin{array}{c}\text { U Mann- } \\
\text { Whitney }\end{array}$ \\
\cline { 2 - 5 } & Average rank & Sum of ranks & Average rank & Sum of ranks & \\
\hline Positive & 35.67 & 1070.00 & 25.33 & 760.00 & $295.000^{* * *}$ \\
\hline Neutral & 26.83 & 805.00 & 34.17 & 1025.00 & $340.000^{*}$ \\
\hline Negative & 25.57 & 767.00 & 35.43 & 1063.00 & $302.000^{* *}$ \\
\hline
\end{tabular}


Note. ${ }^{*} p=$ n.s. ${ }^{* *} p<.006 .{ }^{* * *} p<.005$.

In the case of the studied husbands with higher and lower levels of transgression, we found a similar relationship as for the studied wives (Table 3). Positive emotional connotations of husbands with a higher level of transgression were emphatically greater than husbands with a lower level of transgression (Mann-Whitney test $=232.500, p<.001$ ). While neutral emotional connotations of husbands with a higher level of transgression were emphatically weaker than husbands with a lower level of transgression (Mann-Whitney test = $287.500, p<.02)$. A similar tendency occurred in the case of negative emotional connotations (Mann-Whitney test $=300.00, p<.02)$.

Table 3. Emotional connotations of husbands

\begin{tabular}{|c|c|c|c|c|c|}
\hline \multirow{2}{*}{$\begin{array}{c}\text { Type of } \\
\text { connotation }\end{array}$} & \multicolumn{2}{|c|}{$\begin{array}{l}\text { Husbands with higher level } \\
\text { of transgression }(\mathrm{N}=30)\end{array}$} & \multicolumn{2}{|c|}{$\begin{array}{l}\text { Husbands with lower level } \\
\text { of transgression }(\mathrm{N}=30)\end{array}$} & \multirow{2}{*}{$\begin{array}{l}\text { U Mann- } \\
\text { Whitney }\end{array}$} \\
\hline & Average rank & Sum of ranks & Average rank & Sum of ranks & \\
\hline Positive & 37.75 & 1132.50 & 23.25 & 697.50 & $232.500^{* * *}$ \\
\hline Neutral & 25.08 & 752.50 & 35.92 & 1077.50 & $287.500^{* *}$ \\
\hline Negative & 25.50 & 765.00 & 35.50 & 1065.00 & $300.000^{*}$ \\
\hline
\end{tabular}

Note. ${ }^{*} p<.02 .{ }^{* *} p<.02 .{ }^{* * *} p<.001$.

\section{Discussion}

It has been confirmed the hypothesis that a greater positive affective shift in spouses with higher levels of transgression than in spouses with lower levels of transgression. The hypothesis that a greater negative affective displacement in spouses with a lower level of transgression than in the case of spouses with a higher level of transgression was also confirmed. Probably a higher level of transgression, which is expressed inter alia in innovation, enriching personal competences and courage in taking on new tasks (Studenski, 2006), is a good basis for taking actions that bring satisfaction to both spouses. As a result, positive emotions are stimulated, which are supported by further transgressive activities. The results of research carried out by Ślaski (2012) indicate that women are more characterized by ethical and family transgression, while men professional and material. Despite a quite popular opinion that wives less frequently show satisfaction with their marriage than husbands, which is also expressed in the emotional component, the presented results do not confirm this. Conducted studies on spouses, excluding those undergoing therapy, also indicate a lack of significant differences between women and men in expressing their personal emotional sphere (Jackson et al., 2014). A positive affective shift creates an emotional environment improving the well-being of both spouses, which consequently increases satisfaction with their relationship (Bloch et al., 2014). This could be connected to 
the fact that the more frequently occurring positive emotions stimulate the brain to produce specific mediators, which lengthen the time spouses feel satisfied with their relationship (Berridge \& Kringelbach, 2011). Human brain studies have led to the discovery of neuronal structures that determine experiencing positive emotional states. These include some midbrain structures, the ventral striatum, and anterior insula. From the structural and functional perspective, differentiation of the orbitofrontal cortex is important. The lateral posterior, phylogenetically and ontogenetically older, is more connected to emotional states dependent on bodily rewards; while the later anterior orbitofrontal cortex is responsible for emotional states induced by rewards occurring in later phylogenetic development, caused by activating internal motivation (Sescousse et al., 2010). Positive emotions expressed by both spouses over the long-term also have a positive effect on their physical health (Haase et al., 2016). In turn, too infrequent occurrence of positive emotions in marital interactions in relation to negative emotions, which can be described as a negative affective shift, can cause the development and perpetuation of emotional dysfunctions (Hofmann, 2014).

A significant discovery pertaining to the affective sphere with promising prospects for marital relations is emotional intelligence (Brackett et al., 2005). Numerous studies in this area indicate a dependence between emotional intelligence level and the quality of the marital relationship (Zeidner et al., 2013; Schutte \& Malouff, 2016). Due to the fact that emotional intelligence can be developed, spouses have a chance to attain the quality of relationship that will satisfy them to a greater degree than until now. An important element of emotional intelligence is familiarity with one's own emotions, managing one's own emotions, and recognizing the partner's emotions. Proficiency in this area positively affects creating satisfying marital relations (Malouff et al., 2014). An active awareness involving regular monitoring of events in the spouse's environment can promote noticing and taking into account a spouse's experienced emotions as well as affect adequate expression of one's own emotions. Freshness of perception combined with self-reflection, in contrast to stereotypical perception of one's spouse, diminishes the amount of conflicts that release a series of negative emotions and lower the feeling of satisfaction with the relationship (Jones et al., 2011). The more opportunities spouses have to experience positive emotions, which is supported by a higher level of transgression, the more the likeliness of creating satisfying marital relationships (Shafer et al., 2014).

\section{Conclusions}

The specificity of the affective sphere of the studied spouses, expressed as a positive affective shift, is significantly connected with their level of transgression. Spouses with a higher level of transgression are characterized by a greater positive affective shift than spouses with a lower level of transgression, which in light of the current study results 
indicates a tendency to create satisfying marital relations. In the context of the presented analysis of the obtained study results, the following question comes to mind: Does the level of transgression affect the positive affective shift or are spouses characterized by a positive affective shift more transgressive? Undertaking the difficult task of answering this question can constitute a significant value for marriages of a prophylactic, diagnostic and therapeutic nature. Also the pedagogical aspect is quit important. When spouses create high quality relationship they not only realized themselves but also they are building favorable climate which is helpful in properly educational process their children. Relationship between spouses in fundamental way making educational atmosphere of family, so it is very important to take an attention on their quality. Discovered regularities included in the educational stream e.g. during lessons of education to life in family, can be value clue to this what and how should youth developing to reach the ability to building properly relationships with relatives what increase possibility of create in future happy marriages.

\section{Bibliography}

Bennett, N.G. (2017). A reflection on the changing dynamics of union formation and dissolution, Demographic Research, 36, 371-390, https://doi.org/10.4054/DemRes. 2017.36.12.

Berridge, K.C., \& Kringelbach, M.L. (2011). Building a neuroscience of pleasure and wellbeing, Psychology of Well-Being: Theory, Research and Practice, 1, 1-3, https:// doi.org/10.1186/2211-1522-1-3.

Bloch, L., Haase, C.M., \& Levenson, R.W. (2014). Emotion regulation predicts marital satisfaction: More than a wives' tale, Emotion, 14(1), 130-144, https:// doi.org/ 10.1037/a0034272.

Brackett, M.A., Warner, R.M., \& Bosco, J.S. (2005). Emotional intelligence and relationship quality among couples, Personal Relationships, 12, 197-212, https:/ / doi.org/10.1111/j.1350-4126.2005.00111.x.

Bradley, J.M., \& Hojjat, M. (2016). A model of resilience and marital satisfaction, The Journal of Social Psychology, 1, 1-14, https:// doi.org/10.1080/00224545. 2016.1254592.

Carr, D., Freedman, V.A., Cornman, J.C., \& Schwarz, N. (2014). Happy marriage, happy life? Marital quality and subjective well-being in later life, Journal of Marriage and Family, 76, 930-948, https://doi.org/10.1111/jomf.12133.

Chen, K.-H., Brown, C.L., Wells, J.L., Rothwell, E.S., Otero, M.C., Levenson, R.W., \& Fredrickson, B.L. (2020). Physiological linkage during shared positive and shared negative emotion, Journal of Personality and Social Psychology, https:// doi.org/10.1037/pspi0000337, (dostęp 12.06.2021).

Cherlin, A.J. (2004). The deinstitutionalization of American marriage, Journal of Marriage and Family, 66, 848-861, https:/ / doi.org/10.1111/j.0022-2445.2004.00058.x. 
Costa, P.T., \& McCrae, R.R. (1992). Revised NEO Personality Inventory (NEO-PI-R) and NEO Five-Factor Inventory (NEO-FFI): Professional manual, Psychological Assessment Resources.

Dakowicz, A. (2014a). The affective sphere of spouses with high or low relationship satisfaction, Progress in Health Sciences, 4(2), 96-101.

Dakowicz, A. (2014b). Powodzenie matżeństwa. Uwarunkowania psychologiczne w perspektywie transgresyjnego modelu Józefa Kozieleckiego, Białystok: Wydawnictwo Uniwersyteckie TRANS HUMANA.

Dakowicz, A. (2015a). Marital success from the perspective of Kozielecki's transgression model, Studies in Logic, Grammar and Rhetoric. Cognitive Systems, 40(53), 321-333, https:// doi.org/10.1515/slgr-2015-0016.

Dakowicz, A. (2015b). Specificity of psychon structure forming the personality of transgressive and protective spouses, Polish Psychological Bulletin, 46(4), 535-542, https:// doi.org/10.1515/ppb-2015-0060.

Ekman, P. (1992). Telling lies: Clues to deceit in the marketplace, politics and marriage, New York: W.W. Norton.

Field, A. (2013). Discovering statistics using IBM SPSS statistics. Fourth edition, London: SAGE Publications Ltd.

Frye, N., Ganong, L., Jensen, T., \& Coleman M. (2020). A Dyadic Analysis of Emotion Regulation as a Moderator of Associations Between Marital Conflict and Marital Satisfaction Among First-married and Remarried Couples, Journal of Family Issues, 41(12), 2328-2355, https://doi.org/10.1177/0192513X20935504.

Gelain, M., Pini, M.S., Rossi, F., Venable, K.B., \& Walsh, T. (2013). Local search approaches in stable matching problems, Algorithms, 6 (4), 591-617, https://doi.org/ 10.3390/a6040591.

Goddard, H.W., Olson, J.R., Galovan, A.M., Schramm, D.G., \& Marshall, J.P. (2016). Qualities of character that predict marital well-being, Family Relations. Interdisciplinary Journal of Applied Family Studies, 65(3), 424-438, https:// doi.org/10.1111/fare.12195.

Gottman, J.M., \& Silver, N. (1999). The seven principles for making marriage work, New York: Crown.

Haase, C.M., Holley, S.R., Bloch, L., Verstaen, A., \& Levenson, R.W. (2016). Interpersonal emotional behaviors and physical health: A 20-year longitudinal study of long-term married couples, Emotion, 16 (7), 965-977, https:/ / doi.org/ 10.1037/a0040239.

Hahne, P. (2004). Schluss mit lustig. Das Ende der Spaßgesellschaft, Lahr: Verlag der St. Johannis Druckerei.

Hofmann, S.G. (2014). Interpersonal emotion regulation model of mood and anxiety disorders, Cognitive Therapy and Research, 38(5), 483-492, https://doi.org/ 10.1007/s10608-014-9620-1. 
Jackson, J.B., Miller, R.B., Oka, M., \& Henry, R.G. (2014). Gender differences in marital satisfaction: A meta-analysis, Journal of Marriage and Family, 76, 105-129, https:// doi.org/10.1111/jomf.12077.

Janik McErlean, A.B., \& Lim, L.X.C. (2020). Relationship between Parenting Style, Alexithymia and Aggression in Emerging Adults, Journal of Family Issues, 41(6), 853874, https:/ / doi.org/10.1177/0192513X19886647.

Jones, K.C., Welton, S.R., Oliver, T.C, \& Thoburn, J.W. (2011). Mindfulness, spousal attachment, and marital satisfaction: A mediated model, The Family Journal: Counseling and Therapy for Couples and Families, 19(4), 357-361, https:// doi.org/10.1177/1066480711417234.

Kimmes, J.G., Durtschi J.A., Clifford, Ch.E., Knapp, D.J., \& Fincham F.D. (2015). The role of pessimistic attributions in the association between anxious attachment and relationship satisfaction, Family Relations. Interdisciplinary Journal of Applied Family Studies, 64(4), 547-562, https:/ / doi.org/10.1111/fare.12130.

Kozielecki, J. (2007). Psychotransgresjonizm. Nowy kierunek psychologii, Warszawa: Wydawnictwo Akademickie "Żak".

Madison, J.K., \& Madison, L.S. (2013). A review of research-based interventions on marriage preparation, Journal of Rational-Emotive \& Cognitive-Behavior Therapy, 31(2), 67-74, https:// doi.org/10.1007/s10942-013-0160-5.

Malouff, J.M., Schutte, N.S., \& Thorsteinsson, E.B. (2014). Trait emotional intelligence and romantic relationship satisfaction: A meta-analysis, The American Journal of Family Therapy, 42, 53-66, https:/ / doi.org/ 10.1080/01926187.2012.

Parkinson, B. (2019). Intragroup emotion convergence: beyond contagion and social appraisal, Journal of Personality and Social Psychology Review, 24(2), 121-140, https:// doi.org/10.1177/1088868319882596.

Polenick, C.A., Zarit, S.H., Birditt, K.S., Bangerter, L.R., Seidel, A.J., \& Fingerman, K.L. (2017). Intergenerational support and marital satisfaction: Implications of beliefs about helping aging parents, Journal of Marriage and Family, 79, 131-146, https://doi.org/10.1111/jomf.12334.

Różycka, J., \& Skrzypińska, K. (2011). Perspektywa noetyczna w psychologicznym funkcjonowaniu człowieka, Roczniki Psychologiczne, 14(2), 101-121.

Rubin, A., \& Babbie E. (2008). Research Methods for Social Work. Sixth edition, Belmont: Thomson Higher Education.

Schutte, N.S., \& Malouff, J.M. (2016). Comment on developments in trait emotional intelligence research: A broad perspective on trait emotional intelligence, International Society for Research on Emotion, 8(4), 343-344, https:// doi.org/10.1177/1754073916650499. 
Sescousse, G., Redouté J., \& Dreher, J.C. (2010). The architecture of reward value coding in the human orbitofrontal cortex, The Journal of Neuroscience, 30(39), 13095-13104, https:// doi.org/10.1523/JNEUROSCI.3501-10.2010.

Shafer, K., Jensen, T.M., \& Larson, J.H. (2014). An actor-partner model of relationship effort and marital quality, Family Relations. Interdisciplinary Journal of Applied Family Studies, 63(5), 654-666, https://doi.org/10.1111/fare.12096.

Ślaski, S. (2012). Motywacyjno-osobowościowe wyznaczniki zachowań transgresyjnych i ochronnych, Warszawa: Wydawnictwo Uniwersytetu Kardynała Stefana Wyszyńskiego.

Slatcher, R.B., \& Schoebi, D. (2017). Protective processes underlying the links between marital quality and physical health, Current Opinion in Psychology, 13, 148-152, https:// doi.org/10.1016/j.copsyc.2016.09.002.

Sternberg, R.J. (1997). Introduction to psychology, Orlando: Harcourt Brace College Publishers.

Studenski, R. (2006). Skłonność do ryzyka a zachowania transgresyjne, (w:) M. Goszczyńska, R. Studenski (red.), Psychologia zachowań ryzykownych. Koncepcje, badania, praktyka, 128142, Warszawa: Wydawnictwo Akademickie "Żak”.

Taormina, R.J., \& Gao, J.H. (2013). Maslow and the motivation hierarchy: Measuring satisfaction of the needs, The American Journal of Psychology, 126 (2), 155-177, https:// doi.org/10.5406/amerjpsyc.126.2.0155.

Tsang, L.L.W., Harvey, C.D.H., Duncan, K.A., \& Sommer, R. (2003). The effects of children, dual earner status, sex role traditionalism, and marital structure on marital happiness over time, Journal of Family and Economic Issues, 24, 5-26, https:// doi.org/10.1023/A:1022478919443.

Walker, A. (2004). A symposium on marriage and its future, Journal of Marriage and Family, 66, 843-847, https:// doi.org/10.1111/j.0022-2445.2004.00057.x.

Willoughby, B.J. (2015). The role of marital beliefs as a component of positive relationship functioning, Journal of Adult Development, 22 (2), 76-89, https:// doi.org/10.1007/s10804-014-9202-1.

Wojaczek, K. (2015). Creating an environment of family support in the area of cooperation of the Church, aid institutions and schools, (in:) I. Pešatová, B. Szluz, P. Walawender (eds.), Interdisciplinary approach in social problem solving, 66-74, Ústí nad Labem: Jan Evangelista Purkyne University in Ústí nad Labem.

Zeidner, M., Kloda, I., \& Matthews, G. (2013). Does dyadic coping mediate the relationship between emotional intelligence (EI) and marital quality? Journal of Family Psychology, 27(5), 795-805, https://doi.org/10.1037/a0034009. 